ORIGINAL ARTICLE

\title{
In vitro antimicrobial activity of methanolic extracts from cutaneous secretions of Amazonian amphibians against phytopathogens of agricultural interest
}

\author{
Livia Deice RAASCH-FERNANDES ${ }^{1}$, Solange Maria BONALDO ${ }^{1,3 *} \oplus$, Domingos de Jesus RODRIGUES ${ }^{1}$, \\ Stela Regina FERRARINI², Ana Gabriela Araújo VERÇOSA³ ${ }^{3}$ Daiane Lopes de OLIVEIRA ${ }^{3}$ \\ 'Universidade Federal de Mato Grosso (UFMT), Programa de Pós-Graduação em Ciências Ambientais (PPGCAM), Campus Sinop, Mato Grosso, Brazil \\ 2Universidade Federal de Mato Grosso (UFMT), Instituto de Ciências da Saúde, Sinop, Mato Grosso, Brazil \\ ${ }^{3}$ Universidade Federal de Mato Grosso (UFMT), Instituto de Ciências Agrárias e Ambientais (ICAA), Campus Sinop, Mato Grosso, Brazil \\ * Corresponding author: sbonaldo@ufmt.br; (1) https://orcid.org/0000-0002-2240-2700
}

\begin{abstract}
The biochemical defense mechanisms of amphibians involve cutaneous secretions of bioactive molecules with antimicrobial activity. This study evaluated the in vitro activity of methanolic extracts from cutaneous secretions of two amphibian species of the Bufonidae family, Rhaebo guttatus and Rhinella marina, in the control of the phytopathogens Fusarium udum, Fusarium solani, Colletotrichum truncatum, Aspergillus flavus, Rhizoctonia solani, Macrophomina phaseolina, and Calonectria pseudometrosideri. The R. guttatus extract decreased the mycelial growth of F. udum, F. solani, A. flavus, and M. phaseolina at some tested concentrations. The $R$. marina extract decreased the mycelial growth of $C$. truncatum at the concentration of $0.5 \mathrm{mg} \mathrm{mL}^{-1}$, and inhibited the mycelial growth of $A$. flavus at concentrations of 0.1 and $0.5 \mathrm{mg} \mathrm{mL}^{-1}$, which was similar to the inhibition by the positive control. The $R$. marina extract also decreased the microsclerotia production by $R$. solani at concentrations of 0.2 and $0.3 \mathrm{mg} \mathrm{mL}^{-1}$. In addition, the extracts inhibited conidial sporulation and germination at varying degrees. The inhibition of appressoria formation in C. truncatum by the R. guttatus and R. marina extracts was 85-99\% and 63-100\%, respectively. Our results demonstrated that treatment with extracts from $R$. guttatus and $R$. marina cutaneous secretions showed antifungal activity against the studied phytopathogens.
\end{abstract}

KEYWORDS: inhibition; conidia; Rhaebo guttatus; Rhinella marina

\section{Atividade antimicrobiana in vitro de extratos metanólicos de secreções cutâneas de anfíbios amazônicos sobre fitopatógenos de interesse agrícola}

\section{RESUMO}

Os mecanismos de defesa bioquímica dos anfíbios envolvem secreçôes cutâneas de moléculas bioativas com atividade antimicrobiana. Este estudo avaliou a atividade in vitro de extratos metanólicos da secreçáo cutânea de duas espécies de anfíbios da família Bufonidae, Rhaebo guttatus e Rhinella marina, no controle dos patógenos Fusarium udum, Fusarium solani, Colletotrichum truncatum, Aspergillus flavus, Rhizoctonia solani, Macrophomina phaseolina e Calonectria pseudometrosideri. O extrato de $R$. guttatus inibiu o crescimento micelial de F. udum, F. solani, A. flavus e M. phaseolina em algumas concentraçóes testadas. $\mathrm{O}$ extrato de $R$. marina inibiu o crescimento micelial de $C$. truncatum na concentração de $0,5 \mathrm{mg} \mathrm{mL}^{-1}$, e inibiu o crescimento micelial de $A$. flavus nas concentraçôes de 0,1 e $0,5 \mathrm{mg} \mathrm{mL}^{-1}$, que foi semelhante à inibiçáo pelo controle positivo. $\mathrm{O}$ extrato de $R$. marina também diminuiu a produçáo de microescleródios de $R$. solani nas concentraçóes de 0,2 e $0,3 \mathrm{mg}$ $\mathrm{mL}^{-1}$. Além disso, os extratos inibiram a esporulação e germinação de conídios em graus variados. A inibição da formação de apressórios em C. truncatum pelos extratos de R. guttatus e R. marina foi de 85\%-99\% e 63\%-100\%, respectivamente. Nossos resultados demonstraram que o tratamento com extratos da secreção cutânea de $R$. guttatus e $R$. marina apresentou atividade antifúngica sobre os fitopatógenos estudados.

PALAVRAS-CHAVE: inibição; conídios; Rhaebo guttatus; Rhinella marina

CITE AS: Raasch-Fernandes, L.D.; Bonaldo, S.M.; Rodrigues, D.J.; Ferrarini, S.R.; Verçosa, A.G.A.; Oliveira, D.L. 2021. In vitro antimicrobial activity of methanolic extracts from cutaneous secretions of Amazonian amphibians against phytopathogens of agricultural interest. Acta Amazonica 51 : 145-155 


\section{INTRODUCTION}

The biodiversity of Amazonia is a potential source of chemical compounds of biological and industrial interest (Skirycz et al. 2016). Natural chemotypes have biological activities which result in combinatorial chemistry which, in addition to generating stereo chemically complex structures with many functional groups, also produce compounds which specifically interact with biological targets (Cragg and Newman 2013; Loiseleur 2017).

Natural products have a long history as a source of and inspiration for novel agrochemicals (Sparks et al. 2017). For example, strobilurins are synthetic pyrethroids which are reconfigurations of the core structure isolated from the mycelium of Strobilurus tenacellus (Pers.) Singer (Loiseleur 2017; Sparks et al. 2017). Certain phytochemicals act on various types of diseases and can be applied in the food and agro-industry (Dileep et al. 2013). Compounds obtained from natural products have shown direct fungitoxic action by inhibiting spore germination and mycelial growth of phytopathogens (Stangarlin et al. 2011; Oliveira et al. 2014). In this context, the prospection for new active compounds is relevant to overcome pathogen resistance to existing fungicides, which results from the indiscriminate and excessive use of these substances, leading to a feedback cycle of ever higher concentrations of antifungals and a consequent increase in toxic residues in food products (Barros-Velazquez 2016).

Some animals produce structurally unique secondary metabolites which can be useful as new chemical templates for drug discovery (Cunha-Filho et al. 2010; Banfi et al. 2016). An example is the development of Captopril, a medication derived from small peptides isolated from the venom of a South American snake (Bothrops jararaca Wied-Neuwied), known to potentiate the action of bradykinin (Opie and Kowolik 1995; Harvey 2014).

Such secondary metabolites are also synthesized during metabolism in amphibians (Banfi et al. 2016) and involve defensive adaptations which help protect them against predators, parasites, and microorganisms (Ferreira et al. 2013; Huang et al. 2016). This chemical defense arsenal includes alkaloids and bufadienolides (Ferreira et al. 2013; Perera Córdova et al. 2016), which are secreted by cutaneous glands (Rodríguez et al. 2017), especially in frogs of the Bufonidae family (Schmeda-Hirschmann et al. 2016; Petroselli et al. 2018). Bufadienolides are an important group of steroid hormones with physiological and defense functions (Perera Córdova et al. 2016) that have vasoconstriction (Kamboj et al. 2013), antiviral (Sousa et al. 2017), antitumor (Yuan et al. 2016), cytotoxic (Ferreira et al. 2013; Li et al. 2015), antibacterial and antifungal properties (Rodríguez et al. 2017). Therefore, bufadienolides have potential for use to minimize damage and losses resulting from diseases caused by plant pathogenic fungi (Raasch-Fernandes et al. 2019).
In the present study, we evaluated the in vitro activity of the methanolic extract of the cutaneous secretion of two amphibian species of the Bufonidae family, Rhaebo guttatus (Schneider) and Rhinella marina (Linnaeus), in the control of seven phytopathogenic fungi.

\section{MATERIAL AND METHODS}

\section{Cutaneous secretion extracts and phytopathogen isolates}

The cutaneous secretion was obtained from six individuals of $R$. guttatus and nine of $R$. marina collected in 2015-2016 in Colniza ( $\left.9^{\circ} 13^{\prime} 46.71^{\prime \prime} \mathrm{S}, 60^{\circ} 17^{\prime} 41.75^{\prime \prime} \mathrm{W}\right)$ in the state of Mato Grosso, Brazil (collection license no. 30034-1 issued to D.J. Rodrigues by Instituto Brasileiro do Meio Ambiente e dos Recursos Naturais - IBAMA/SISBIO). The procedure for collecting the cutaneous secretion of the animals is non invasive and does not cause harm to ther animals. All sampled animals were returned to nature after the procedure. Voucher specimens were deposited in the Biologic Collection of Meridional Amazonia-ABAM/UFMT/Sinop (R. guttatus - ABAM-H 1538 and $R$. marina-ABAM-H 1262) in the context of another study (Oliveira et al. 2019). The secretion was extruded by manual compression of the parotoid macrogland. The collected material was dried in silica gel, extracted three times in methanol, and evaporated on a rotary evaporator. The methanolic extracts were weighed, diluted in sterile water, and filtered through a Millipore membrane $(0.22 \mu \mathrm{m})$ (Ferreira et al. 2013). These procedures were carried out in the Laboratory of Chemical Research (LiPeQ) of UFMT/Sinop.

We obtained the isolates of seven phytopathogenic fungi from the mycoteque of UFMT: Fusarium udum E.J. Butler, Mem. and Fusarium solani (Mart.) Sacc. (causing agents of Fusarium wilts), Colletotrichum truncatum (Schwein.) Andrus and W.D. Moore (anthracnose), Aspergillus flavus Link (Aspergillus rot), Rhizoctonia solani J.G. Kühn (root rot), Macrophomina phaseolina (Tassi) Goid (gray root rot) and Calonectria pseudometrosideri R.F. Alfenas, L. Lombard, Crous and A.C. Alfenas (leaf spot). All these phytopathogens are found in agricultural crops in northern Mato Grosso state. The pathogens were grown in Petri dishes containing potato dextrose agar (PDA) culture medium, which was prepared using $39 \mathrm{~g}$ of the commercial product (Acumedia) and incubated in a BOD chamber at $25^{\circ} \mathrm{C}$ for approximately 10 days. For $C$. pseudometrosideri, $20 \mathrm{~g} \mathrm{~L}^{-1}$ of agar-agar (Micromed) was added to the prepared PDA medium for culturing and testing.

\section{Antimicrobial activity assays}

All assays were conducted in the Laboratory of Phytopathology and Microbiology of UFMT/Sinop. To test the effect of the extracts on F. udum, F. solani, C. truncatum, A. flavus, R. solani, and $M$. phaseolina, we used concentrations of $0.1,0.2,0.3$, 0.4 , and $0.5 \mathrm{mg} \mathrm{mL}^{-1}$ of the methanolic extracts of $R$. guttatus 
and $R$. marina cutaneous secretions (Raasch-Fernandes et al. 2019), sterile water as negative control, and a fungicide mixture of metconazole $\left(80 \mathrm{mg} \mathrm{mL}^{-1}\right)+$ pyraclostrobin $\left(130 \mathrm{mg} \mathrm{mL}^{-1}\right)$ (Opera Ultra EC; BASF Corporation) as positive control. To test the effect on $C$. pseudometrosideri, we used the same extract concentrations and negative control, and azoxystrobin $(200 \mathrm{mg}$ $\left.\mathrm{mL}^{-1}\right)+$ cyproconazole $\left(80 \mathrm{mg} \mathrm{mL}^{-1}\right)$ (Priori Xtra; Syngenta Crop Protection AG) as positive control. The fungicides were applied at the recommended dosage rate: metconazole + pyraclostrobin $\left(0.65+0.40 \mathrm{mg} \mathrm{mL}^{-1}\right)$ and azoxystrobin + cyproconazole $\left(0.50+0.20 \mathrm{mg} \mathrm{mL}^{-1}\right)$.

The antifungal activity of the methanolic extracts was evaluated by determining the mycelial growth using the disc-diffusion test in PDA medium (Bauer et al. 1966). Four sterilized filter-paper discs with a 5-mm diameter were soaked in the treatment solution and arranged equidistant on a 9-cm petri dish, and a 5-mm mycelial disc was deposited on the center of each petri dish. Five replicates were used for each treatment and each control. Each petri dish constituted one replicate. The petri dishes were sealed and incubated in a BOD incubator at $25^{\circ} \mathrm{C}$ in the dark. Evaluations were performed at the same time every day by measuring colony diameter along two orthogonal axes (average of two diametrically opposed measurements) starting $24 \mathrm{~h}$ after dish preparation.

The mycelial growth (MG) and the mycelial growth rate index (MGRI) were evaluated until one of the treatments reached two thirds of the surface of the petri dish in all replicates (Costa and Carvalho et al. 2013; Andrade et al. 2018). The mycelial growth rate index was subsequently calculated from the mycelial growth data:

$$
\mathrm{FMGRI}=\frac{\sum(\mathrm{D}-\mathrm{Da})}{\mathrm{N}}
$$

where MGRI = mycelial growth rate index, $\mathrm{d}=$ current average diameter of the colony; $\mathrm{da}=$ average diameter of the colony from the previous day and, $\mathrm{n}=$ number of days after inoculation (Dias et al. 2005; Maia et al. 2011).

The mycelial growth inhibition percentage (MGI\%) was determined according to the methodology proposed by Edgington et al. (1971).

The effects of the extracts on the sporulation of F. udum, F. solani, C. truncatum, A. flavus, and C. pseudometrosideri were analyzed after completing the mycelial growth assay (covering two thirds of the petri dish). After this period, 10 $\mathrm{mL}$ of sterile water were added to each petri dish, and then each fungal colony was scraped. The resulting suspension was filtered through a gauze and the number of conidia was counted in a Neubauer chamber under an optical microscope. The obtained data were converted into sporulation inhibition percentage (SI\%) for each treatment relative to the negative control (Fernandes et al. 2015).
The effect of the extracts on the production of $R$. solani microsclerotia was determined after completing the mycelial growth assay (21 days of incubation of the mycelial disc). Each petri dish was divided into four equal quadrants starting at the central mycelial disc. A scale score was used for the visual quantification of the number of microsclerotia as follows: ++++ indicates a large number, +++ a moderate number, ++ a small number, + a very small number, and - the absence of microsclerotia. The sum of the scores was converted to a numerical scale from 0 to 4 for statistical analysis.

The effect of the extracts on the conidial germination of $F$. udum, C. truncatum, and C. pseudometrosideri was evaluated according to the methodology proposed by Stangarlin et al. (1999). Colonies of the fungal pathogens cultured in PDA medium for approximately 10 days were used to obtain the conidial suspension. Sterile water $(10 \mathrm{~mL})$ was added to the fungal cultures, and the cultures were scraped with a Drigalski loop and then filtered through a sterile gauze. After filtration, the suspension was adjusted to the following concentrations using a Neubauer chamber: $1 \times 10^{4}, 1 \times 10^{5}$, and $5 \times 10^{4}$ conidia $\mathrm{mL}^{-1}$ for C. pseudometrosideri, C. truncatum, and $F$. udum, respectively. Conidial germination was evaluated under an optical microscope (400x magnification) using 100 conidia per repetition. Germination was deemed to have occurred when the germ tube emerged.

Sterile 96-well microplates were used to evaluate conidial germination (Almeida et al. 2009). In this study, an aliquot of $40 \mu \mathrm{L}$ of the suspension of the evaluated phytopathogens was deposited in each well. A $40-\mu \mathrm{L}$ aliquot of the treatments was subsequently added to each well. For the control, $40 \mu \mathrm{L}$ sterile water were added instead of the treatments. The conidial germination assays were performed with eight replications for each treatment. The plates were incubated at $25^{\circ} \mathrm{C}$ for 3, 6, and $24 \mathrm{~h}$ for C. pseudometrosideri, C. truncatum, and F. $u d u m$, respectively. After the incubation period, germination was interrupted with $20 \mu \mathrm{L}$ of blue cotton and lactophenol. This period was determined with preliminary germination tests of the conidia of each phytopathogen in sterile water.

A Drigalski-loop scattering method was used to evaluate the conidial germination of $A$. flavus. This method was used because the conidia of $A$. flavus did not germinate when using microplates in preliminary tests. Petri dishes of 9-cm diameter were used, where each plate was considered one replicate, with eight replicates per treatment level (5) or control (2) and two treatments ( $R$. guttatus and $R$. marina extracts). The plates were filled with agar-water medium and $100 \mu \mathrm{L}$ of the test solution was distributed on the medium after solidification using a sterile Drigalski loop. After $2 \mathrm{~h}, 100 \mu \mathrm{L}$ of conidial suspension $\left(2.6 \times 10^{6}\right.$ conidia $\left.\mathrm{mL}^{-1}\right)$ of $A$. flavus were added and spread using a sterile Drigalski loop. Plates were incubated at $25^{\circ} \mathrm{C}$ in the dark and evaluated after $48 \mathrm{~h}$, when germination was interrupted with $20 \mu \mathrm{L}$ of blue cotton and lactophenol. The 
results were expressed as conidial germination inhibition percentage (CGI\%) for each treatment level compared to the negative control (Fernandes et al. 2015). The germination of $F$ solani was not evaluated because there was no conidial production for this isolate.

For C. truncatum, we evaluated the emergence of the appressoria in conidial germination assays (Bonaldo et al. 2004) and expressed this variable as the appressorial formation inhibition percentage (AFI\%) relative to the negative control. A total of 100 randomly selected germinated conidia per repetition were examined for number of appressoria, totaling 800 conidia per treatment. Post-germination appressoria development was averaged using an optical microscope.

\section{Statistical analysis}

The assays were conducted in a completely randomized design and the data were analyzed using the SISVAR version 4.3 program (Ferreira 2008). The results of each extract were subjected to analysis of variance (ANOVA) using the F-test, and the means were compared by the Scott-Knott test $(\mathrm{p}<0.05)$. The original SI\% data did not meet the requirements of normality and homogeneity and were therefore transformed to $(x+1)^{0,5}$.

\section{RESULTS}

The $R$. guttatus extract significantly decreased MG and MGRI of F. udum, F. solani, A. flavus and M. phaseolina (Table 1; Figure 1). MG and MGRI of $F$ udum were significantly lower for the $0.5-\mathrm{mg} \mathrm{mL}^{-1}$ concentration relative to the negative control. MG was lower in the concentration of $0.5 \mathrm{mg} \mathrm{mL}^{-1}$ $(5.21 \mathrm{~cm})$ in relation to the negative control $(6.60 \mathrm{~cm})$. This concentration also showed reduced MGRI $\left(0.74 \mathrm{~cm} \mathrm{day}^{-1}\right)$ in relation to the negative control $\left(0.94 \mathrm{~cm} \mathrm{day}^{-1}\right) . \mathrm{MG}$ and MGRI of $F$. solani were significantly lower at all $R$. guttatusextract concentrations compared with the negative control, with MG values of 5.71, 5.96, 5.48, 5.62, and $5.84 \mathrm{~cm}$ for 0.1 , $0.2,0.3,0.4$ and $0.5 \mathrm{mg} \mathrm{mL}^{-1}$, respectively (negative control $=7.18 \mathrm{~cm}$ ), and corresponding MGRI values of $0.71,0.75$, $0.69,0.70$, and $0.73 \mathrm{~cm} \mathrm{day}^{-1}$, respectively (negative control average $\left.=0.90 \mathrm{~cm} \mathrm{day}^{-1}\right)$. This suggests that the $R$. guttatus extract has properties which reduce in vitro development of $F$ solani at the tested concentrations.

MG and MGRI of $A$. flavus were significantly lower than the negative control at 0.1 and $0.5 \mathrm{mg} \mathrm{mL}^{-1}(\mathrm{MG}=4.20$ and $4.13 \mathrm{~cm}$, respectively, and negative control $=6.78 \mathrm{~cm})$. The MGRI was lower at $0.1 \mathrm{mg} \mathrm{mL}^{-1}(0.47 \mathrm{~cm})$ and $0.5 \mathrm{mg} \mathrm{mL}^{-1}$ $(0.46 \mathrm{~cm})$ relative to the negative control $(0.75 \mathrm{~cm}) . \mathrm{MG}$ of $M$. phaseolina was significantly lower at $0.1,0.2$ and $0.3 \mathrm{mg} \mathrm{mL}^{-1}$, with mean values of $6.88,7.53$, and $7.76 \mathrm{~cm}$, respectively, relative to the negative control $(7.94 \mathrm{~cm})$. MG was lower at 0.1 $\mathrm{mg} \mathrm{mL}^{-1}$, differing from the other concentrations. The MGRI of $M$. phaseolina was significantly lower than the negative control $(2.65 \mathrm{~cm})$ at $0.1 \mathrm{mg} \mathrm{mL}^{-1}(2.29 \mathrm{~cm})$.

MG and MGRI of $C$. pseudometrosideri indicated colony development promotion at 0.1 and $0.2 \mathrm{mg} \mathrm{mL}^{-1}$ compared

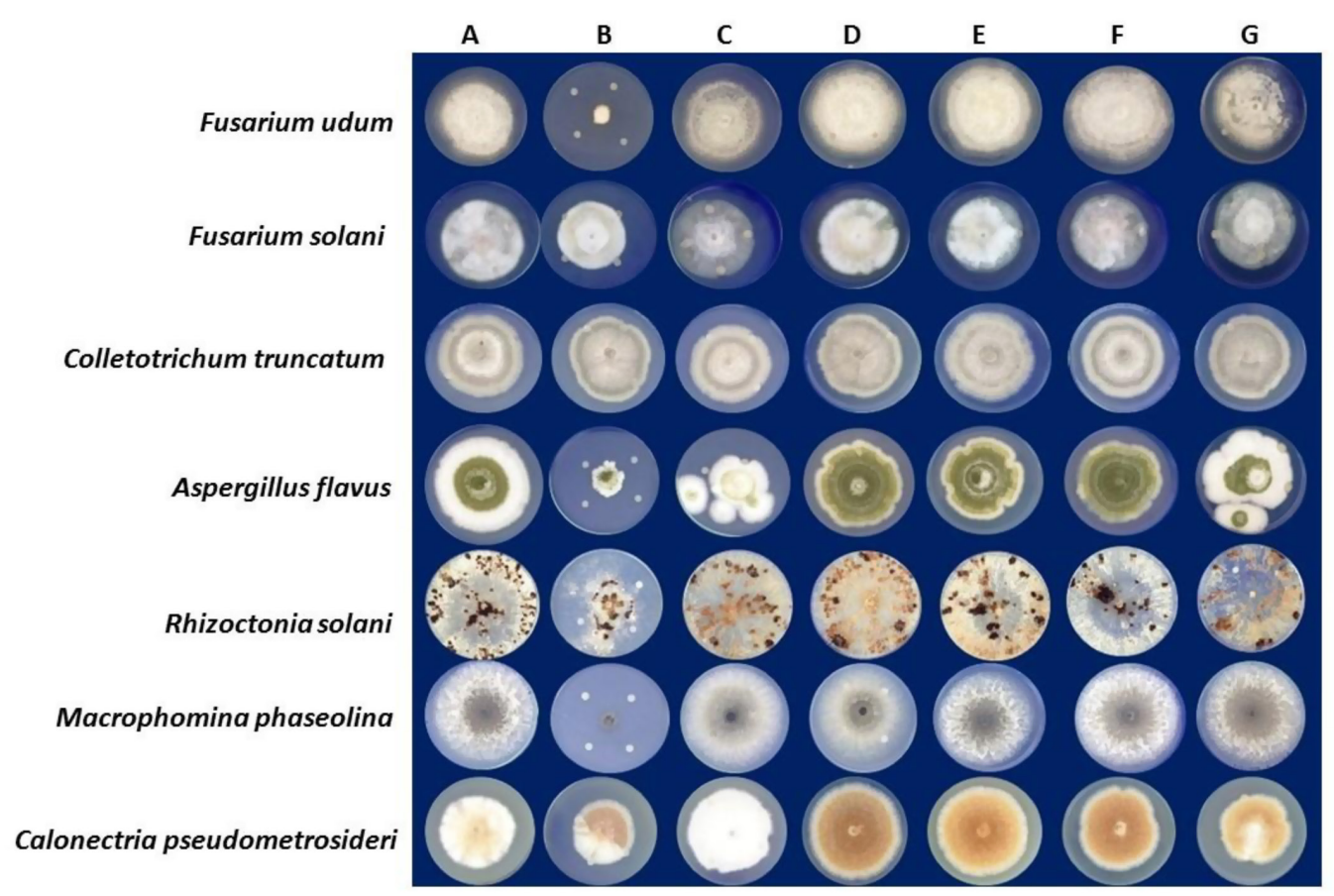

Figure 1. Growth of mycelial colonies of the pathogens Fusarium udum, Fusarium solani, Colletotrichum truncatum, Aspergillus flavus, Rhizoctonia solani, Macrophomina phaseolina, and Calonectria pseudometrosideri treated with the methanolic extract of Rhaebo guttatus cutaneous secretion. A - negative control (sterile water); B - positive control (fungicide); $C$ - extract concentration $0.1 \mathrm{mg} \mathrm{mL}^{-1} ; \mathrm{D}-0.2 \mathrm{mg} \mathrm{mL}^{-1} ; \mathrm{E}-0.3 \mathrm{mg} \mathrm{mL}^{-1} ; \mathrm{F}-0.4 \mathrm{mg} \mathrm{mL}^{-1} ; \mathrm{G}-0.5 \mathrm{mg} \mathrm{mL}^{-1}$. This figure is in color in the electronic version. 


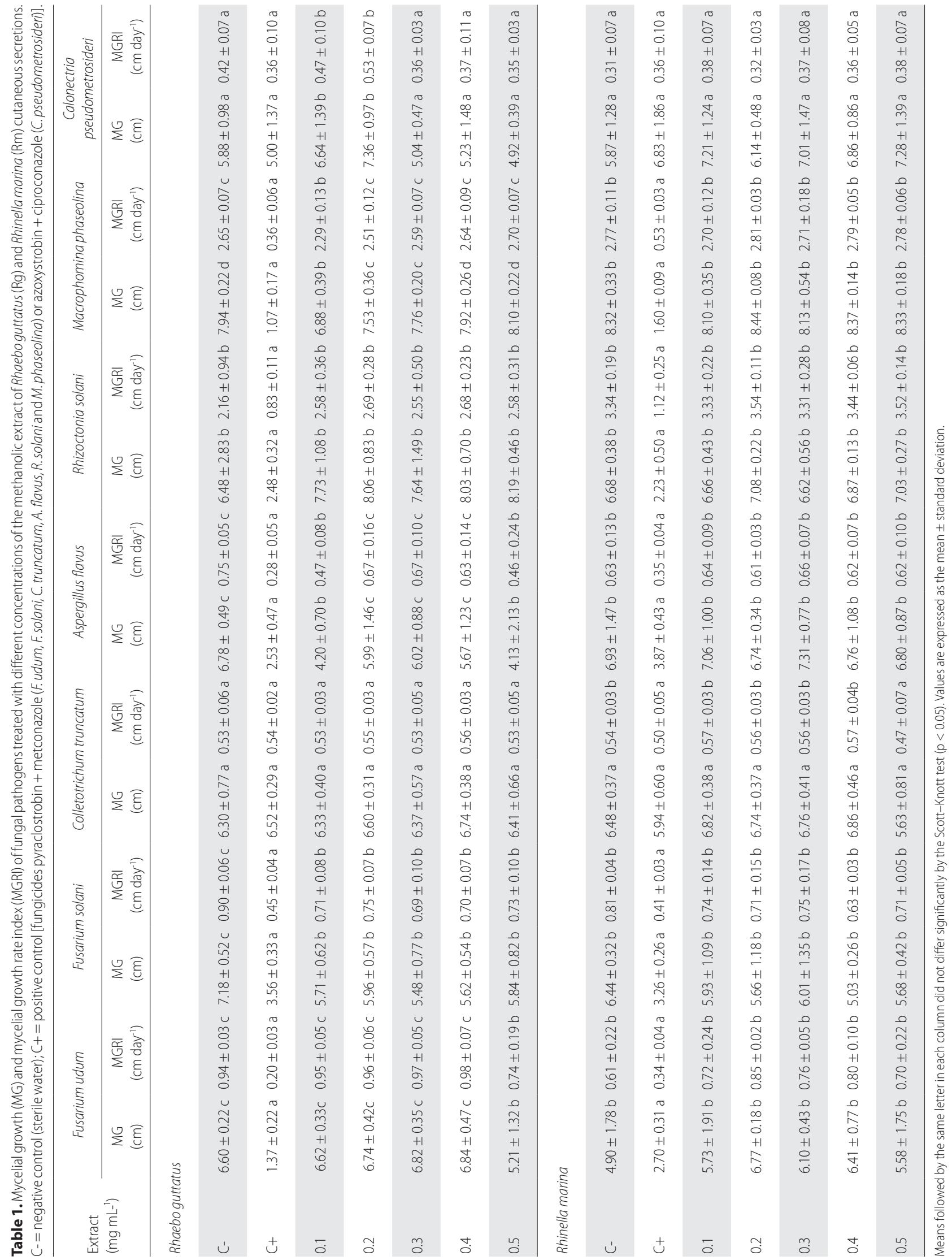


with the negative control. MG mean values were 6.64 and 7.36 $\mathrm{cm}$ at 0.1 and $0.2 \mathrm{mg} \mathrm{mL}^{-1}$, respectively, while the negative control showed $5.88 \mathrm{~cm}$. MGRI was higher at 0.1 and $0.2 \mathrm{mg}$ $\mathrm{mL}^{-1}$, with mean values of 0.47 and $0.53 \mathrm{~cm} \mathrm{day}^{-1}$, respectively, relative to the negative control $\left(0.4 \mathrm{~cm} \mathrm{day}^{-1}\right)$. These data suggest that lower concentrations showed no beneficial effects in the mycelial growth reduction of $C$. pseudometrosideri.

The $R$. marina extract did not decrease the mycelial growth relative to the negative control (Table 1). The positive control significantly inhibited mycelial growth in $F$. udum, F. solani, A. flavus, R. solani, and M. phaseolina (Table 1; Figure 2). The MGRI of $C$. truncatum was reduced at $0.5 \mathrm{mg} \mathrm{mL}^{-1}(0.47$ $\left.\mathrm{cm} \mathrm{day}^{-1}\right)$ when compared with the negative control $(0.54$ $\mathrm{cm}$ day $\left.^{-1}\right)$, and did not differ significantly from the positive control $\left(0.50 \mathrm{~cm} \mathrm{day}^{-1}\right)$.

The R. guttatus extract inhibited the MGI\% of F. udum, A. flavus and C. pseudometrosideri (Table 2). MGI\% of $F$. udum increased by $21.3 \%$ at $0.5 \mathrm{mg} \mathrm{mL}^{-1}$ and also increased significantly in A. flavus at $0.1 \mathrm{mg} \mathrm{mL}^{-1}(38.0 \%)$ and $0.5 \mathrm{mg}$ $\mathrm{mL}^{-1}(40.6 \%)$, thus showing fungitoxic effect of the extract at these concentrations. The MGI\% of $C$. pseudometrosideri at $0.3,0.4$ and $0.5 \mathrm{mg} \mathrm{mL}^{-1}$ did not differ significantly from the positive control. The $R$. marina extract increased the MGI\% of C. truncatum at $0.5 \mathrm{mg} \mathrm{mL}^{-1}$ to a similar level to the positive control (Table 2).
The $R$. guttatus extract significantly affected the sporulation inhibition (SI\%) in A. flavus at 0.1 and $0.5 \mathrm{mg} \mathrm{mL}^{-1}(93.1$ and $83.6 \%$, respectively), showing similar toxic effect to the positive control (95.9\%) (Table 3). The SI\% of A. flavus for the $R$. marina extract at $0.4 \mathrm{mg} \mathrm{mL}^{-1}(54.9 \%)$ showed similar results to the positive control (85.7\%).

Microsclerotia production in $R$. solani was significantly reduced at 0.2 and $0.3 \mathrm{mg} \mathrm{mL}^{-1}$ of the $R$. marina extract when compared with the negative and positive control (Table 4).

The conidial germination of $F$ udum was significantly inhibited at $0.3 \mathrm{mg} \mathrm{mL}^{-1}(55.5 \%)$ of the $R$. guttatus extract, which did not differ significantly from the positive control (83.9\%). The CGI\% values for C. pseudometrosideri at 0.3 , 0.4 and $0.5 \mathrm{mg} \mathrm{mL}^{-1}$ showed germination inhibition of 50.9, 55.4 and 50.9\%, respectively (Table 4). Appressoria formation of $C$. truncatum was inhibited by both extracts. The $R$. guttatus extract inhibited AFI\% at $0.2,0.3$ and 0.4 $\mathrm{mg} \mathrm{mL}^{-1}$ (99.2, 95.6 and $98.3 \%$, respectively), which did not differ significantly from the positive control (100\%). The $R$. marina extract at $0.1,0.2,0.3$ and $0.4 \mathrm{mg} \mathrm{mL}^{-1}$ did not differ significantly from the positive control (100\%), with mean AFI\% values of 100, 98.2, 95.1 and $98.2 \%$, respectively. These results suggest that higher concentrations showed no beneficial effects in the appressoria formation of $C$. truncatum.

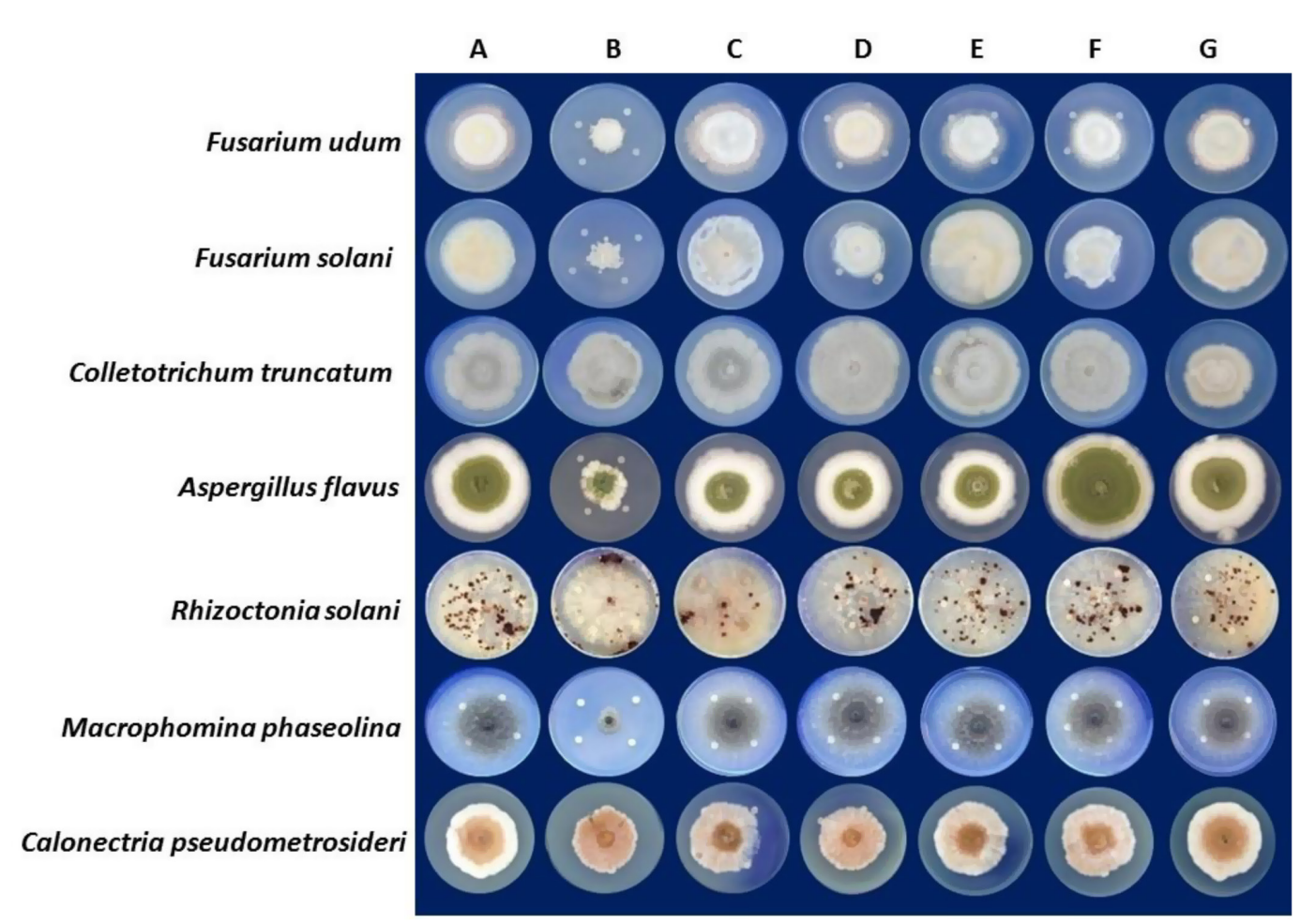

Figure 2. Growth of the mycelial colonies of the pathogens Fusarium udum, Fusarium solani, Colletotrichum truncatum, Aspergillus flavus, Rhizoctonia solani, Macrophomina phaseolina, and Calonectria pseudometrosideri treated with the methanolic extract of Rhinella marina cutaneous secretion. A - negative control (sterile water); B - positive control (fungicide); $C$ - extract concentration $0.1 \mathrm{mg} \mathrm{mL}^{-1} ; \mathrm{D}-0.2 \mathrm{mg} \mathrm{mL}^{-1} ; \mathrm{E}-0.3 \mathrm{mg} \mathrm{mL}^{-1} ; \mathrm{F}-0.4 \mathrm{mg} \mathrm{mL}^{-1} ; \mathrm{G}-0.5 \mathrm{mg} \mathrm{mL}^{-1}$. This figure is in color in the electronic version. 


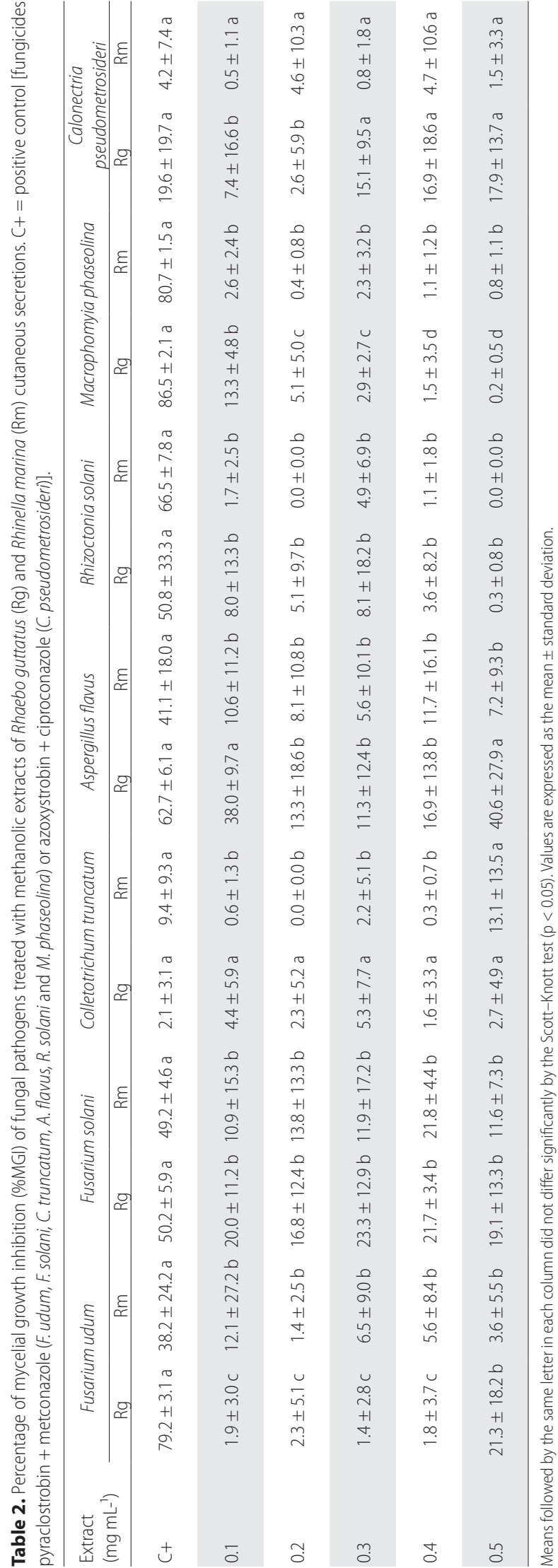

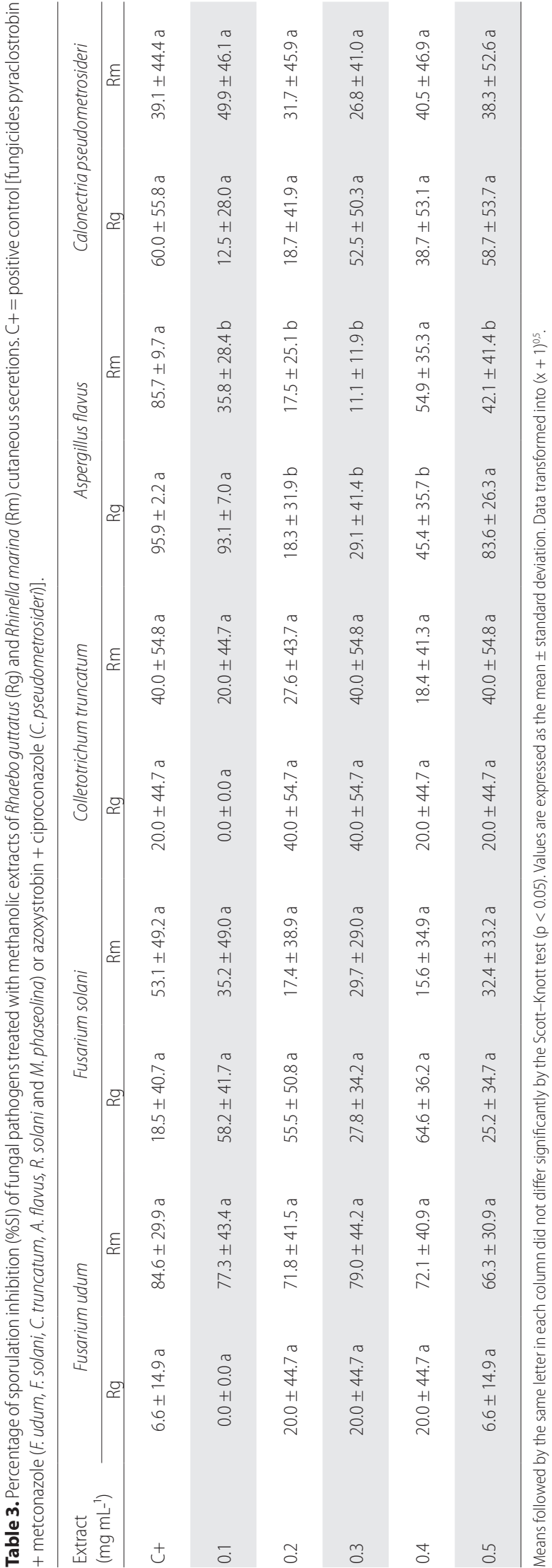




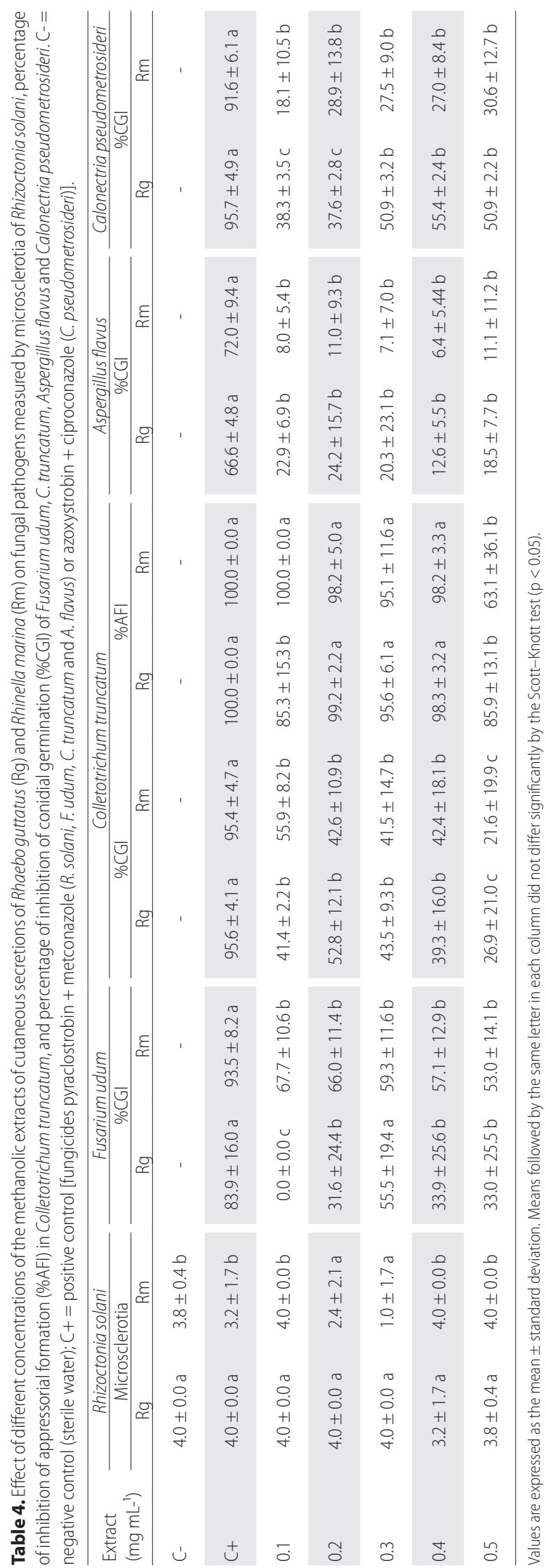

\section{DISCUSSION}

The reduction in MG, MGRI, MGI\% and CGI\% by the $R$. guttatus extract at $0.5 \mathrm{mg} \mathrm{mL}^{-1}$ suggests antifungal activity against $F$. udum. The $R$. guttatus extract also had a fungitoxic effect on the development of $F$. solani, as all concentrations inhibited MG, even at the lowest concentration.

There is no information in the literature on the fungitoxic effect of secondary metabolites in extracts originating from animals against Fusarium Link ex Grey, 1821. Antifungal activity on MG of $F$ s solani had been reported for the crude aqueous extracts of the floral buds of clove (Syzygium aromaticum (L.) Merr. \& L.M.Perry) (Venturoso et al. 2011), and essential oil of thyme (Thymus vulgaris L.), which resulted in complete inhibition of mycelium development even at lower concentrations of the extracts (Krzyśko-Łupicka et al. 2016).

The in vitro response of the MG, MGRI and MGI\% of $A$. flavus to the $R$. guttatus extract is of particular importance as this fungus is of major concern in agriculture. It produces highly carcinogenic toxins called aflatoxins in the seeds of a number of crops both before and after harvest which are a health hazard to animals (Adeyeye 2016), causing negative impact on the nutritional value of plants and considerable yield losses (Klich 2007; Htoon et al. 2019). The R. guttatus extract showed similar MG inhibition of A. flavus as the positive control agent in all tests, which makes it a candidate for future prospection against this phytopathogen.

The R. guttatus extract presented fungitoxic effect on $M$. phaseolina only in the lower concentrations. The action mechanisms involved in antifungal activities in phytopathogens by bioprospecting secondary metabolites of animals are still unknown. However, a higher inhibition rate at a lower concentration $\left(50 \mu \mathrm{g} \mathrm{mL} \mathrm{L}^{-1}\right)$ was observed using crude aqueous extracts of ginger (Zinziber officinalis Roscoe) on banana fibers infected with Helminthosporium sp. Link as compared to higher concentrations $(100,200$, and $400 \mu \mathrm{g}$ $\mathrm{mL}^{-1}$ ) (Rodrigues et al. 2006).

The antifungal effect of lower concentrations of $R$. guttatus extract on M. phaseolina, as well as its effect on the promotion of MG in C. pseudometrosideri, may be related to the interaction among chemical constituents of the extract. An extract can present compounds that stimulate pathogen growth (Venturoso et al. 2011). Thus, the relative amount of stimulating compounds and their half-lives, as well as the interaction between them, determines the action on the phytopathogen.

The $R$. marina extract reduced the MGRI of $C$. truncatum. This reduction is promising because the fungicide used as positive control was not very effective in controlling this pathogen. This response may be related to constant applications of the same fungicide over time. Constantly exposing the pathogen population to high rates of a fungicide may add undue selection pressure on the population, which in 
turn may lead to resistance or tolerance (Deising et al. 2008). Thus, a change in the pathogen at this point can render the fungicide less effective or ineffective.

The sporulation inhibition of $A$. flavus by both extracts may be an important result, as this pathogen produces large quantities of asexual spores (conidia) which promote fungal dissemination (Mah and Yu 2006). Pimentel et al. (2010) also observed a significant reduction in sporulation of $A$. flavus with the essential oil from fresh leaves of Tanaecium nocturnum (Barb. Rodr.) Bureau \& K.Schum using the contact and fumigation techniques. Likewise, the microsclerotia production inhibition observed in the treatment with the $R$. marina extract may be relevant, because these resistance structures ensure pathogen survival in adverse conditions, even in the absence of the host and in unfavorable climate conditions (Ritchie et al. 2013). Microsclerotia can remain in the soil and in organic matter after plant infection and serve as inocula for subsequent cultures (Chawla et al. 2012), with potential for more severe and frequent epidemics (Ma et al. 2015).

The inhibition of appressoria formation by both $R$. guttatus and $R$. marina extracts is also relevant, because pathogens with these structures can directly penetrate the intact surface of the host and remain at this point of contact, dissolve the tissue, and form a small hole in the tissue (Bergamin Filho et al. 1995). Consequently, inhibiting the emergence of this structure can contribute to controlling the disease caused by $C$. truncatum because its appressoria act as specialized infection structures formed from a hypha or germ tube and are important for fungal penetration through the leaf surface of the host (Khan and Hsiang 2003).

The difference in the antifungal activity of the $R$. guttatus and $R$. marina extracts observed in our study could be attributed to factors such as the existence of many receptors of the extract which select phytochemicals with different affinities in the receptors of the phytopathogens (Ahuja et al. 2012; Fesel and Zucca 2016), or the insufficient amount of active compound in the test concentrations (Oliveira et al. 2017). Also, the active principle may be present in the test concentrations, but other constituents are exerting antagonistic effects on the bioactive compounds (Caesar and Cech 2019). Although the bufadienolides are the main active components in the cutaneous secretion of $R$. marina and $R$. guttatus, there are interspecific differences in the number and type of constituents (Ferreira et al. 2013). Four bufadienolides are found in the $R$. marina cutaneous secretion (telocinobufagin, marinobufagin, bufalin and resibufogenin) and one in the secretion of $R$. guttatus (marinobufagin) (Banfi et al. 2016).

We used crude extracts containing several active compounds which have similar or synergistic activities that inhibit or promote pathogen growth. The advantage of using such extracts as antimicrobial agents is the lower risk of microbial resistance, because their high complexity limits microbial adaptability (Daferera et al. 2003). A crude (untreated) extract from any source of natural products typically contains novel, structurally diverse chemical compounds (Lahlou 2013), as well as active, partially active, or many inactive compounds (Cragg and Newman 2013). Therefore, it is necessary to study the application of these extracts through isolation processes, to evaluate more precisely the potential of the isolated compounds and understand their effective action in controlling the phytopathogens tested.

Our results present a potentially novel source of fungitoxic substances. The $R$. guttatus extract had a beneficial effect on reducing mycelial growth, and also lower concentrations of the extract showed antifungal activity. Our study provides a basis for further studies examining the antifungal activity of secondary metabolites produced by amphibians on phytopathogens of agricultural interest.

\section{CONCLUSIONS}

The methanolic extract of the cutaneous secretion of Rhaebo guttatus caused mycelial growth inhibition of Fusarium udum, Fusarium solani, Aspergillus flavus and Macrophomina phaseolina at a range of concentrations. Furthermore, all extract concentrations inhibited mycelial growth of Fusarium solani. The extract also inhibited Aspergillus flavus sporulation and conidia germination of Fusarium udum similarly to the positive control fungicide. The Rhinella marina extract inhibited the mycelial growth of Colletotrichum truncatum and microsclerotia production of Rhizoctonia solani. Both extracts decreased appressoria formation of Colletotrichum truncatum to the same level of the positive control. The results suggest that the $R$. guttatus extract has higher antifungal activity against the analyzed phytopathogens, but that both extracts represent a potential alternative for inhibiting appressoria formation and the consequent penetration through the leaf surface by phytopathogenic fungi. Further studies are needed to determine the bioactive compounds responsible for the antifungal activity of the extracts. The Rhaebo guttatus and Rhinella marina extracts should be tested in other phytopathogen fungi which affect the agricultural crops in the region. Our results provided relevant information for assays with components derived from secondary metabolites of amphibian species on the growth of phytopathogens.

\section{ACKNOWLEDGMENTS}

We are grateful to Coordenaçáo de Aperfeiçoamento de Pessoal de Nível Superior (CAPES), Fundação de Amparo à Pesquisa do Estado de Mato Grosso (FAPEMAT), Conselho Nacional de Desenvolvimento Científico e Tecnológico (CNPQ) and Institute of Agricultural and Environmental Sciences (ICAA)/UFMT). 


\section{REFERENCES}

Adeyeye, S.A.O. 2016. Fungal mycotoxins in foods: A review. Cogent Food \& Agriculture, 2: 1-11.

Ahuja, I.; Kissen, R.; Bones, A.M. 2012. Phytoalexins in defense against pathogens. Trends in Plant Science, 17: 73-90.

Almeida, T.F.; Camargo, M.; Panizzi, R.C. 2009. Efeito de extratos de plantas medicinais no controle de Colletotrichum acutatum, agente causal da flor preta do morangueiro. Summa Phytopathologica, 35: 196-201.

Andrade, B.; Matias, R.; Corrêa, B.; Oliveira, A.; Guidolin, D.; Roel, A. 2018. Phytochemistry, antioxidant potential and antifungal of Byrsonima crassifolia on soil phytopathogen control. Brazilian Journal of Biology, 78: 140-146.

Banfi, F.F.; Guedes, K.S.; Andrighetti, C.R.; Aguiar, A.C.; Debiasi, B.W.; Noronha, J.C.; Rodrigues, D.J.; Vieira Júnior, G.M.; Sanchez, B.A.M. 2016. Antiplasmodial and cytotoxic activities of toad venoms from Southern Amazon, Brazil. Korean Journal of Parasitology, 54: 415-421.

Barros-Velazquez, J. 2016. Antimicrobial Food Packaging. 1st ed. San Diego: Academic Press/Elsevier, San Diego, 676p.

Bauer, A.W.; Kirby, E.M.; Sherris, J.C.; Turk, M. 1966. Antibiotic susceptibility testing by standardized single disk method. American Journal of Clinical Pathology, 45: 493-496.

Bergamin Filho, A.; Kimati, H.; Amorim, L. 1995. Manual de Fitopatologia: Princípios e Conceitos. 3rd ed. Agronômica Ceres, Sáo Paulo, 919p.

Bonaldo, S.M.; Schwan-Estrada, K.R.F.; Stangarlin, J.R.; Tessmann, D.J.; Scapim, C.A. 2004. Fungitoxicidade, atividade elicitora de fitoalexinas e proteção de pepino contra Colletotrichum lagenarium, pelo extrato aquoso de Eucalyptus citriodora**. Fitopatologia Brasileira, 29: 128-134.

Caesar, L.K.; Cech, N.B. 2019. Synergy and antagonism in natural product extracts: when $1+1$ does not equal 2. Natural Product Reports, 36: 869-888.

Chawla, S.; Woodward, J.E.; Wheeler, T.A. 2012. Influence of Verticillium dabliae infested peanut residue on wilt development in subsequent cotton. International Journal of Agronomy, 2012: 212075.

Costa e Carvalho, R.R.; Laranjeira, D.; Carvalho Filho, J.L.S.; Souza, P.S.; Blank, A.F.; Alves, P.B.; et al. 2013. In vitro activity of essential oils of Lippia idoides and Lippia gracilis and their major chemical components against Thielaviopsis paradoxa, causal agent of stem bleeding in coconut palms. Quimica Nova, 36: 241-244.

Cragg, G.M.; Newman, D.J. 2013. Natural products: A continuing source of novel drug leads. Biochimica et Biophysica Acta, 1830: 3670-3695.

Cunha-Filho, G.A.; Resck, I.S.; Cavalcanti, B.C.; Pessoa, C.O.; Moraes, M.O.; Ferreira, J.R.; et al. 2010. Cytotoxic profile of natural and some modified bufadienolides from toad Rhinella schneideri parotoid gland secretion. Toxicon, 56: 339-348.

Daferera, D.J.; Ziogas, B.N.; Polissiou, M.G. 2003. The effectiveness of plant essential oils on the growth of Botrytis cinerea, Fusarium sp. and Clavibacter michiganensis subsp. michiganensis. Crop Protection, 22: 39-44.
Deising, H.B.; Reimann, S.; Pascholati, S.F. 2008. Mechanisms and significance of fungicide resistance. Brazilian Journal of Microbiology, 39: 286-295.

Dias, M.B; Pozza. E.A.; Abreu, M.S.; Miranda, E.O. 2005. Efeito da temperatura no crescimento micelial, produção e germinaçâo de conídios de Colletotrichum spp. isolados de Coffea arabica L. Ciência e Agrotecnologia, 29: 545-552.

Dileep, N.; Junaid, S.; Rakesh, K.N.; Kekuda, P.T.R.; Nawaz, N.A.S. 2013. Antifungal activity of leaf and pericarp of Polyalthia longifolia against pathogens causing rhizome rot of ginger. Science, Technology and Arts Research Journal, 2: 56-59.

Edgington, L.V.; Knew, K.L.; Barron, G.L. 1971. Fungitoxic spectrum of benzimidazole compounds. Phytophatology, 61: 42-44.

Fernandes, L.C.B.; Albuquerque, C.C.; Júnior, R.S.; Oliveira, F.F.M.; Gurgel, E.P.; Mesquita, M.V.; et al. 2015. Fungitoxicity of plant extracts and essential oil of Lippia gracilis Schauer on the fungus Monosporascus cannonballus Pollack and Uecker. Summa Phytopathologica, 41: 153-155.

Ferreira, D.F. 2008. SISVAR: um programa para análises e ensino de estatística. Revista Symposium, 6: 36-44.

Ferreira, P.M.P.; Lima, D.J.B.; Debiasi, B.W.; Soares, B.M.; Machado, K.C.; Noronha, J.C.; et al. 2013. Antiproliferative activity of Rhinella marina and Rhaebo guttatus venom extracts from Southern Amazon. Toxicon, 72: 43-51.

Fesel, P.H.; Zuccaro, A. 2016. $\beta$-glucan: Crucial component of the fungal cell wall and elusive MAMP in plants. Fungal Genetics and Biology, 90: 53-60.

Harvey, A.L. 2014. Toxins and drug discovery. Toxicon, 92: 193-200.

Htoon, W.; Kaewpradit, W.; Vorasoot, N.; Toomsan, B.; Akkasaeng, C.; Puppala, N.; et al. 2019. Relationships between nutrient uptake and nitrogen fixation with aflatoxin contamination in peanut under terminal drought. Agronomy, 9: 419. doi. org/10.3390/agronomy9080419

Huang, L.; Li, J.; Anboukaria, H.; Luo, Z.; Zhao, M.; Wu, H. 2016. Comparative transcriptome analyses of seven anurans reveal functions and adaptations of amphibian skin. Scientific Reports, 6: 1-11.

Kamboj, A.J.; Rathour, A.; Kaur, M. 2013. Bufadienolides and their medicinal utility: a review. International Journal of Pharmacy and Pharmaceutical Sciences, 5: 20-27.

Khan, A.; Hsiang, T. 2003. The infection process of Colletotrichum graminicola and relative aggressiveness on four turfgrass species. Canadian Journal of Microbiology, 49: 433-442.

Klich, M.A. 2007. Environmental and developmental factors influencing aflatoxin production by Aspergillus flavus and Aspergillus parasiticus. Mycoscience, 48: 71-80.

Krzyśko-Łupicka, T.; Oraibi, S.M.; Kurp, E.; Walkowiak, W. 2016. A possible use of selected essential oils and citrosept to inhibit the growth of Fusarium solani Mart. (Sacc.). Advances in Microbiology, 6: 1159-1165.

Lahlou M. 2013. The success of natural products in drug discovery. Pharmacology \& Pharmacy, 4: 17-31.

Li, B.J.; Tian, H.Y.; Zhang, D.M.; Lei, Y.H.; Wang, L.; Jiang, R.W.; et al. 2015. Bufadienolides with cytotoxic activity from the skins of Bufo bufo gargarizans. Fitoterapia, 105: 7-15. 
Loiseleur, O. 2017. Natural products in the discovery of agrochemicals. Chimia, 1: 810-822.

Ma, L.; Qiao, J.; Kong, X.; Zou, Y.; Xu, X.; Chen, X.; et al. 2015. Effect of low temperature and wheat winter-hardiness on survival of Puccinia striiformis f. sp tritici under controlled conditions PLoS ONE, 10: e0130691.

Mah, J-H.; Yu, J-H. 2006. Upstream and downstream regulation of asexual development in Aspergillus fumigatus. Eukaryotic Cell, 5: 1585-1595.

Maia, F.G.M.; Armesto, C.; Zancan, W.L.A.; Maia, J.B.; Abreu, M.S. 2011. Efeito da temperatura no crescimento micelial, produção e germinação de conídios de Colletotrichum spp. isolados de mangueira com sintomas de antracnose. Bioscience Journal, 27: 205-210.

Oliveira, A.K.M.; Rizzi, E.S.; Pereira, K.C.L.; Bono, J.A.M; Pina, J.C.; Matias, R. 2017. Phytochemical analysis and fungicide potential of Pouteria ramiflora against Lasiodiplodia theobromae. Horticultura Brasileira, 35: 564-570.

Oliveira, A.F.; Castoldi, L.; Vieira Junior, G.M.; Monção Filho, E.S.; Chaves, M.H.; Rodrigues, D.J.; Sugui, M.M. 2019. Evaluation of antimutagenic and cytotoxic activity of skin secretion extract of Rhinella marina and Rhaebo guttatus (Anura, Bufonidae). Acta Amazonica, 49: 145-151.

Oliveira, J.S.B.; Biondo, V.; Schwan-Estrada, K.R.F. 2014. Extratos e tinturas vegetais sobre o crescimento micelial de Corynespora cassiicola e indução de fitoalexinas em soja. Revista UNINGÁ Review (Online), 17: 5-10.

Opie, L.H.; Kowolik, H. 1995. The discovery of captopril: from large animals to small molecules. Cardiovascular Research, 30: 18-25.

Perera Córdova, W.H.; Leitão, S.G.; Cunha-Filho, G.; Bosch, R.A.; Alonso, I.P.; Pereda-Miranda, R.; et al. 2016. Bufadienolides from parotoid gland secretions of Cuban toad Peltophryne fustiger (Bufonidae): Inhibition of human kidney $\mathrm{Na}(+) / \mathrm{K}(+)$-ATPase activity. Toxicon, 110: 27-34.

Petroselli, G.; Raices, M.; Jungblut, L.D.; Pozzi, A.G.; Erra-Balsells, R. 2018. MALDI-MS argininyl bufadienolide esters fingerprint from parotoid gland secretions of Rhinella arenarum: Age, gender, and seasonal variation. Journal of Mass Spectrometry, 53: 465-475.

Pimentel, F.A.; Cardoso, M.G.; Batista, L.R.; Guimarães, L.G.L.; Silva, D.M. 2010. Ação fungitóxica do óleo essencial de Tanaecium nocturnum (Barb. Rodr.) Bur. e K. Shum sobre o Aspergillus flavus isolado da castanha-do-Brasil (Bertholletia excelsa). Acta Amazonica, 40: 213-220.

Raasch-Fernandes, L.D.; Bonaldo, S.M.; Rodrigues, D.J.; VieiraJunior, G.M.; Schwan-Estrada, K.R.F.; Silva, C.R.; et al. 2019. Induction of phytoalexins and proteins related to pathogenesis in plants treated with extracts of cutaneous secretions of southern Amazonian Bufonidae amphibians. PLoS ONE, 14: e0211020.
Ritchie, F.; Bain, R.; Mcquilken, M. 2013. Survival of sclerotia of Rhizoctonia solani AG3PT and effect of soil-borne inoculum density on disease development on potato. Journal of Phytopathology, 161: 180-189.

Rodrigues, E.; Schwan-Estrada, K.R.F.; Stangarlin, J.R.; Cruz, M.E.S.; Fiori-Tutida, A.C.G. 2006. Avaliação da atividade antifúngica de extratos de gengibre e eucalipto in vitro e em fibras de bananeira infectadas com Helminthosporium sp. Acta Scientiarum Agronomy, 28: 123-127.

Rodríguez, C.; Rollins-Smith, L.; Ibáñez, R.; Durant-Archibold, A.A.; Gutiérrez, M. 2017. Toxins and pharmacologically active compounds from species of the Family Bufonidae (Amphibia, Anura). Journal of Ethnopharmacology, 198: 235-254.

Schmeda-Hirschmann, G.; Quispe, C.; Theoduloz, C.; de Sousa Jr, P.T.; Parizotto, C. 2014. Antiproliferative activity and new argininyl bufadienolide esters from the "cururú" toad Rhinella (Bufo) schneideri. Journal of Ethnopharmacology, 155: 1076-1085.

Skirycz, A.; Kierszniowska, S.; Méret, M.; Willmitzer, L.; Tzotzos, G. 2016. Medicinal Bioprospecting of the Amazon Rainforest: A Modern Eldorado? Trends in Biotechnology, 34: 781-790.

Sousa, L.Q.; Machado, K.D.; Oliveira, S.F.; Araujo, L.D.; MonçấoFilho, E.D.; Melo-Cavalcante, A.A.; et al. 2017. Bufadienolides from amphibians: a promising source of anticancer prototypes for radical innovation, apoptosis triggering and $\mathrm{Na}+\mathrm{K}+$-ATPase inhibition. Toxicon, 127: 63-76.

Sparks, T.M.; Hahn, D.R.; Garizi, N.V. 2017. Natural products, their derivatives, mimics and synthetic equivalents: role in agrochemical discovery. Pest Management Science, 73: 700-715.

Stangarlin, J.R.; Kuhn, O.J.; Assi, L.; Schwan-Estrada, K.R.F. 2011. Control of plant diseases using extracts from medicinal plants and fungi. In: Méndez-Vilas, A. (Ed.). Science Against Microbial Pathogens: Communicating Current Research and Technological Advances. Formatex, Badajoz, p.1033-1042.

Stangarlin, J.R.; Schwan-Estrada, K.R.F.; Cruz, M.E.S.; Nozaki, M.H. 1999. Plantas medicinais e controle alternativo de fitopatógenos. Biotecnologia Ciência \& Desenvolvimento, 2: 16-21.

Venturoso, L.R.; Bacchi, L.M.A.; Gavassoni, W.L.; Conus, L.A.; Pontim, B.C.A.; Souza, F.R. 2011. Inibição do crescimento in vitro de fitopatógenos sob diferentes concentraçôes de extratos de plantas medicinais. Arquivos do Instituto Biológico, 78: 89-95.

Yuan, B.; He, J.; Kisoh, K.; Hayashi, H.; Tanaka, S.; Si, N.; et al. 2016. Effects of active bufadienolide compounds on human cancer cells and CD4+CD25+Foxp3+ regulatory $\mathrm{T}$ cells in mitogen-activated human peripheral blood mononuclear cells. Oncology Reports, 36: 1377-1384.

RECEIVED: 04/12/2019

ACCEPTED: 19/02/2021

ASSOCIATE EDITOR: Jorge Maurício David 